\title{
Research on nitrification and denitrification kinetics of three-phase biological fluidized bed with four step-feed process
}

\author{
Bing Wang ${ }^{1, a}$, Lan Fang ${ }^{2, b^{*}}$ \\ ${ }^{12}$ School of Municipal and Environmental Engineering in Shenyang Jianzhu University, Liaoning \\ Shenyang,110168, China

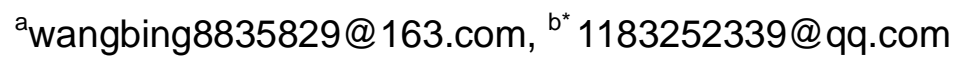

\begin{abstract}
Keywords:biological, fluidized bed,step-feed,SND,kinetic
Abstract. Step-feed nitrogen removal process, as a new sewage treatment technology, was concerned by scholars domestically and abroad in recent years. Three-phase biological fluidized bed with four step-feed process combined step-feed nitrogen removal with biological fluidized bed. In fact,there were many advantages, such as high nitrogen removal efficiency, saving the return facility and so on. Based on the classic dynamic model of activated sludge, simultaneous nitrification and denitrification kinetics of three-phase biological fluidized bed step-feed process were studied. Dynamic model of SND was established and to guide the test and the actual project.
\end{abstract}

\section{Introduction}

In recent years, the phenomenon of sewage putted into water had grown year by year, sewage has seriously affected industry and agriculture. Currently the cities' sewage mainly used the traditional process, but water quality was not up to standard, it was a major problem of operation, so on the basis of energy conservation, upgrading of the sewage treatment technology was a serious problem.

Three-phase biological fluidized bed with four step-feed process was a new biological nitrogen removal process. There were many advantages, such as high nitrogen removal efficiency, saving the return facility, no external carbon source, improving the system resistance and increasing the concentration of activated sludge ${ }^{[1-3]}$. However, this process in our country was not yet mature, there was still a lot of research work to be done.

\section{Experiment equipment}

Experiment equipment was adopted the volume of 20L transparent plexiglass, equipment was shown in Figure 1. Long was $500 \mathrm{~mm}$, width was $200 \mathrm{~mm}$, high was $300 \mathrm{~mm}$. The experiment was divided into four $\mathrm{A} / \mathrm{O}$, each volume was equal and made with aerobic zone and anoxic zone.

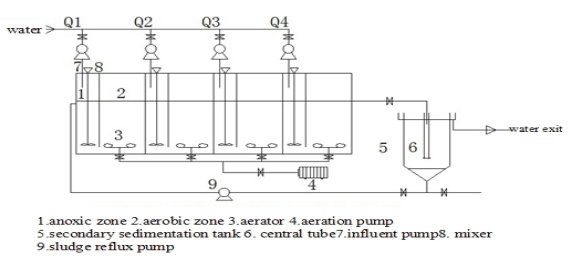

Fig.1 Test device flowchart

\section{The test results and discussion}

\section{SND phenomenon}

In test, the decrement of $\mathrm{NH}_{4}{ }^{+}-\mathrm{N}$ was $0.64 \mathrm{~g} / \mathrm{d}$ in the first section of aerobic zone, the formation of $\mathrm{NO}_{3}{ }^{-} \mathrm{N}$ was $0.27 \mathrm{~g} / \mathrm{d}$. The decrement of $\mathrm{NH}_{4}{ }^{+}-\mathrm{N}$ was $0.58 \mathrm{~g} / \mathrm{d}$ in the second section, the formation of $\mathrm{NO}_{3}{ }^{-}-\mathrm{N}$ was $0.34 \mathrm{~g} / \mathrm{d}$. The decrement of $\mathrm{NH}_{4}{ }^{+}-\mathrm{N}$ was $0.52 \mathrm{~g} / \mathrm{d}$ in the third section, the formation of $\mathrm{NO}_{3}{ }^{-} \mathrm{N}$ was $0.4 \mathrm{~g} / \mathrm{d}$. The decrement of $\mathrm{NH}_{4}{ }^{+}-\mathrm{N}$ was $0.50 \mathrm{~g} / \mathrm{d}$ in the fourth section, the formation of $\mathrm{NO}_{3}{ }^{-} \mathrm{N}$ was $0.36 \mathrm{~g} / \mathrm{d}$. The results showed that the decrement of $\mathrm{NH}_{4}{ }^{+}-\mathrm{N}$ was higher than the formation of $\mathrm{NO}_{3}{ }^{-} \mathrm{N}$, especially in the first and second section, it could inferred that SND 
phenomenon occurred in system. In the step- feed process, sludge only returned to the first section of anoxic zone and the sewage was extended into the segments, so there was gradient distribution of the concentration of sludge in the reaction. In the process of growth and metabolism of microorganisms needed to consume a portion of nitrogen to synthesize their own material, so it occurred loss of nitrogen phenomenon. Whether SND phenomenon occurred in the system or not, it should first deduct the amount of anabolic nitrogen effect of sludge ${ }^{[4]}$.

The microorganisms empirical formula can be estimated the nitrogen used for consumed for assimilation ${ }^{[5]}$, as shown in Table 1 . The results showed the decrement of $\mathrm{NH}_{4}{ }^{+} \mathrm{N}$ in the system was significantly greater than the amount of nitrogen for cell synthesis.

Table1 Nitrogen consumed for assimilation

\begin{tabular}{|c|c|c|c|c|}
\hline Number & $\begin{array}{l}\text { Sludge } \\
\text { emissions (g/d) }\end{array}$ & Nitrogen consumed for assimilation(g/d) & The total amount of nitrogen & $\operatorname{loss}(g / d)$ \\
\hline 1 & 3.388 & 0.406 & 0.650 & \\
\hline 2 & 3.307 & 0.396 & 0.877 & \\
\hline 3 & 3.382 & 0.413 & 0.911 & \\
\hline
\end{tabular}

In test, supposed the growth of microbial cells and sludge emissions were flatted and estimated the amount of nitrogen needed for microbial assimilation. The results of comparison of the nitrogen used for consumed for assimilation and the decrement of $\mathrm{NH}_{4}{ }^{+}-\mathrm{N}$ in the system were shown in Fig.2, it showed that nitrogen used for consumed for assimilation significantly less than the decrement of $\mathrm{NH}_{4}{ }^{+}-\mathrm{N}$ in the system. The decrement of $\mathrm{NH}_{4}{ }^{+}-\mathrm{N}$ in the aerobic zone was not caused by the nitrogen used for consumed for assimilation, so SND phenomenon occurred in the system ${ }^{[6]}$.

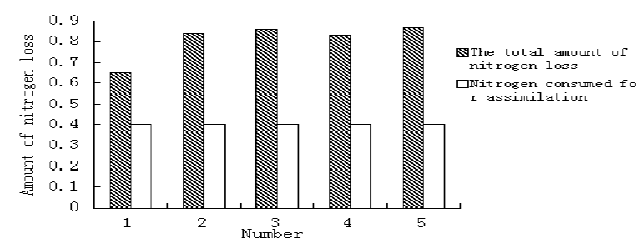

Fig.2 Comparison of the nitrogen used for consumed for assimilation and the TN loss in the aerobic zone

\section{Model assumptions}

Before the derivation of model, assuming the following conditions were satisfied:

(1)The mixture in the reactor was completely in mixed state.

(2)Nitrification and denitrification were independent and meet with Monod equation.

(3)Keeping the number of microorganisms was constant.

(4)Ignore nitrogen consumed for assimilation.

\section{SND kinetics}

In nitrificated ammonia of biological sewage treated process, nitrite was easily be oxidized, so it can approximate that the final product of ammonification was nitrated in the system.

Material balance to $\mathrm{NO}_{3}{ }^{-} \mathrm{N}$, get:

$$
\frac{d D}{d t}=\left(\frac{d D}{d t}\right)_{\text {Nitrificat ion }}+\left(\frac{d D}{d t}\right)_{\text {Denitrific ation }}+\left(\frac{d D}{d t}\right)_{\text {Assimilati on }}
$$

Above formula $\quad \frac{d D}{d t}--\mathrm{NO}_{3}{ }^{-} \mathrm{N}$ degradative rate $(\mathrm{mg} /(\mathrm{L} \cdot \mathrm{d}))$;

Ignore the low concentrations of nitrite nitrogen, so:

$$
\left(\frac{d D}{d t}\right)_{\text {Nitrificat ion }}=-\left(\frac{d N}{d t}\right)_{\text {Nitrificat ion }}
$$

By assumption (4),

$$
\left(\frac{d D}{d t}\right)_{\text {Assimilati on }}=0
$$


In reactions, microbial growth and substrated degradation can be expressed as:

$$
Y_{n}=-\frac{d X_{n}}{d N}=-\frac{\frac{d X_{n}}{d t}}{\frac{d N}{d t}}=\frac{r}{v}=\frac{\frac{r}{X_{n}}}{\frac{v}{X_{n}}}=\frac{\mu_{n}}{q_{n}}
$$

Above formula $\quad \mathrm{Yn}--$ Nitrobacteria yield coefficient $\left(\mathrm{gVSS} / \mathrm{gNH}_{4}{ }^{+}-\mathrm{N}\right)$;

$r-$ Nitrobacteria proliferative rate $(\mathrm{gVSS} / \mathrm{d})$;

$v--\mathrm{NH}_{4}{ }^{+}-\mathrm{N}$ degradative rate $\left(\mathrm{gNH}_{4}{ }^{+}-\mathrm{N} / \mathrm{d}\right)$;

$q_{n}--\mathrm{NH}_{4}{ }^{+}-\mathrm{N}$ ratio oxidative rate $\left(\mathrm{gNH}_{4}{ }^{+}-\mathrm{N} /(\mathrm{gVSS} \cdot \mathrm{d})\right)$

$\mu_{n}--$ Nitrobacteria ratio growth rate $(\mathrm{g} / \mathrm{g} \cdot \mathrm{d})$.

By assumption (3)

$$
\frac{X_{A}}{X}=m
$$

Above formula $m$ - The proportion of nitrobacteria accounting on the total amount of microbes Put ( 4 ) and ( 5 ) into ( 2 ), get:

$$
\left(\frac{d D}{d t}\right)_{\text {Nitrificat ion }}=\frac{1}{Y_{n}} \mu_{n, m} \frac{N}{K_{n}+N} \times \frac{C_{o}}{K_{o}+C_{o}} m X
$$

By the nitration process may be deduced for the denitrificative process:

$$
\left(\frac{d D}{d t}\right)_{\text {Denitrific ation }}=-\frac{1}{Y_{d}} \mu_{d, m} \frac{D}{K_{d}+D} \times \frac{S}{K_{S}+S} \times \frac{K_{o}}{K_{o}+C_{o}} n X
$$

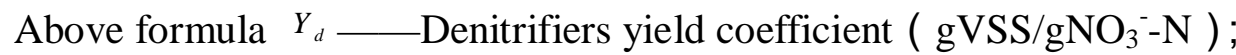

$n$ _ The proportion of denitrifiers accounting on the total amount of microbe $(\%)$. Put ( 6 ) and ( 7 ) into ( 2 ), ignore of assimilation,

$$
\frac{d D}{d t}=\frac{1}{Y_{n}} \mu_{n, m} \frac{N}{K_{n}+N} \times \frac{C_{o}}{K_{o}+C_{o}} m X-\frac{1}{Y_{d}} \mu_{d, m} \frac{D}{K_{d}+D} \times \frac{S}{K_{S}+S} \times \frac{K_{o}}{K_{o}+C_{o}} n X
$$

The formula (8) could be simplified to,

$$
\left(\frac{d D}{d t}\right)_{\text {Nirificat ion }}=\frac{N}{K_{n}+N} \times A
$$

Above formula $A=\frac{1}{Y_{n}} \mu_{n, m} \frac{C_{o}}{K_{o}+C_{o}} m X$, it was a constant.

Because $\mathrm{N}$ was much larger than $K_{n}$, so

$$
\frac{N}{K_{n}+N} \approx 1
$$

So it can get, 


$$
\frac{d N}{d t}=-\left(\frac{d D}{d t}\right)=-A
$$

Considered $\frac{s}{K_{s}+S}$ as a constant, so the formula (7) could be simplified into,

$$
\left(\frac{d D}{d t}\right)_{\text {Denirific ation }}=-B \frac{D}{K_{d}+D}
$$

Put ( 9 ) and ( 12 ) into ( 8 ), get,

$$
\frac{d D}{d t}=A-B \frac{D}{K_{d}+D}
$$

The formula (13) on both sides had to be integrated,

$$
t=\frac{D}{A-B}+\frac{B K d}{(A-B)^{2}} \ln \left[\frac{A K d d}{A K d+(A-B) D}\right]
$$

A could be obtained by testing, under the conditions that $\mathrm{C} / \mathrm{N}$ was 8 , influent split ratio was 1.18, the results were shown in Fig.3 . A was 3.0822 from the slope of figure. Put A into formula(14) and it could obtain that B was 2.81 and $K_{d}$ was 4.9, and put them into formula(14), get:

$$
\frac{d D}{d t}=3.0822-\frac{2.82 D}{4.79+D}
$$

From the model can be seen that $K_{d}$ was $4.7 \mathrm{mg} / \mathrm{L}$, which was much larger than the constant saturation of single-stage denitrificative process. When the dynamic model of SND was established, it used the mixture of $\mathrm{NO}_{3}{ }^{-} \mathrm{N}$ concentration to instead of real $\mathrm{NO}_{3}{ }^{-} \mathrm{N}$ concentration of anoxic zone, but in aerobic zone, the main force of matrix diffusion existed from aerobic zone of biofilm to the internal anoxic zone, the $\mathrm{NO}_{3}{ }^{-} \mathrm{N}$ concentration in actual anoxic zone was lower than the $\mathrm{NO}_{3}{ }^{-} \mathrm{N}$ concentration of mixture, which lead to a higher $K_{d}$.

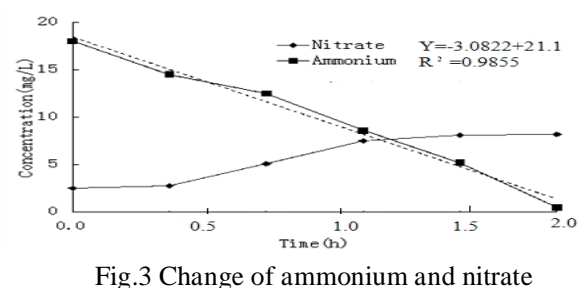

\section{Conclusion}

( 1 ) SND phenomenon existed in three-phase biological fluidized bed with four step-feed process of the aerobic zone;

( 2 ) Dynamic model of SND was established, $\mathrm{R}^{2}=0.9855$;

( 3 ) Dynamic modeling could be used to guide test and actual project, which fully into account in the phase of operational requirements design of the system .

\section{References}

[1] BingWang ,HongJunHan,WeiWang.Nitrogen removal and simultaneous nitrification and denitrification in fluidized bed step-feed process. Journal of Environmental Sciences. 2012: 24(2). 
[2] Bing Wang, Feng Guo Hui , LiYa Feng .The Application of fluidized carrier in Reconstruction Project of sewage plant. Advanced Materials Research.2012.

[3] Bing Wang, Zhang Jiku, Li Yafeng, Li Jun . The application of BP neural network on research of DO influence on fluidized bed step-feed process. ICCAHE 2012.

[4] Klangduen P, Jürg K. Study of factors affecting simultaneous nitrification and denitrification (SND)[J]. Water Science and Technology, 1999, 39(6): 61-68.

[5] Zhou J, Dou Y Y, He Q, et al. Influence Of Step-Feed Style on Denitrification Efficiency In Multistage Biofilm Reactor[J]. Technology of Water Treatment, 2010, 36(1): 106-109.

[6] Lee M W, Park J M. One-Dimensional Mixed-Culture Biofilm Model Considering Different Space Occupancies of Particulate Components[J]. Water Research, 2007, 41(19): 4317-4328. 